\title{
STANFORD'S SONGS
}

Tensa is nothing more difficult to write than a critical eseay on the work of a contemporary. The vocabulary of appreciation is worn threadbare, and is further suspect as being inspired and coloured by the personsl predilections or prejudices of the writer. The perspective is limited to the lifetime of both parties concerned, and there is nothing to tell us definitely whether the work will stand the acid test of time. Durability is the one proof-positive of its soundness, and who can positively say what will endure? Each generation claims, and proclaims, its own immortality and the inevitable disintegration of its immediate predecessor. It is the saddest thing in art that the child disowes its parents. The rung of the ladder which the foot has just left is invariably rotten; yet it has helped the climber a step nearer the stars. Partisanship is the parasite of progress; the average reader is asked. with or against his will, to skgimilate the coloured view of the school to which the writer happens to belong.

But there is one individual, and only one, in musio who oan approsah the subject from a new and less prejudiced point of view, and that is the interpreter. He is the tertius gaudens, the sole beneficiary in the tamily quarrel, for he is out to get the best of everybody in every eoneo of the word. His technical standards are ready made for him in the soope of his instrument, and he has a vast literature in his own subject, built upon the same foundation, on which to form his taste and make his comparisons in idiom. It is this very scope of his instrument which is his safeguard and makes his views dependable; for the work of a composition, if it cannot be pleyed or sung, is nil, and he is the judge. His bona fides is above question by all the rules of common sense; for altruism is a poor substitute for bread, and if for friendship's. sake he tries to force upon the public music in which he does not himself believe, he is bound sooner or later-in the language of our cousins - " to come up againgt the door of the poorhouse with a dull thud."

The interpreter in song stands alone in his art in that his rocal instrument has never varied in its structure, and its tochnique has remained comparatively unaltered trom time immemorial. The potentislities of the voice are the same in the twentieth century as they were in the sixteenth, and the composers of each period have had the same matarial to work with. The Ballade in $\theta$ minor could never bave been written in the days of the elavichord, but the tenor (if it was a tenor) who sang "Have you seen but a whyte lilie growe" could heve sung the Forging Bonge trom Biegfried equally well so far as his apparatus was concerned. The singer by this very immutability 
of his means has but one technical stendard by which to messure his music, and for him the paramount question is-Does the writer of the song know the instrument for which he is writing? If not, his labour is in vain.

Let me say at once that in the matter of Stanford's songs $I$, too, Im a partisan. I could not very well be otherwise, seeing that I have been present at the birth of all the song-cycles from the "Irish Idyll " to "The Songs of the Fleet," and many of the miscellaneous songs as well. These heve contained for me all that I want in song-lilt, rhythm, sense of words, sense of atmosphere, musical imagery and illustration, directness of purpose and-guiding them all-imagination, humour and economy.

But in one thing Stanford stands in a place by himself. I say unreservedly, in the light of a pretty wide acquaintence with the anthology of song, that in his knowledge of the handling of the voice he stands higher than any writer since Schubert. In all the years I have sung his songs I can never remember having had to ask hin to alter a pasage or note on account of technical difficulty. That knowledge was no doubt absorbed in his childhood. His father was a famous amateur bass singer in Dublin in the days of the great ltalians, and was the personal friend of Lablache, who taught him the part of Leporello and spoke of him es his " second self." He sang Elijah in 1847 in Dublin, and Tho Creation and St. Paul and Samson, because he was better than any professional they could get. His tame there is abiding. It is no wonder that singing should have no searets for his son.

In the wide range of Btanford's songs, from grave to gay, there is not one that is not ridiculously easy to sing, and that is the highest tribute you can pay to workmanship. Why are the "Bea-Songs" and the "Fleet-Songs" sung every day throughout the country? Beceuse the composer knew how to bring them within the scope of every ainger who knew his business-not by writing down to him, but by his intimate knowledge of his instrument. He knows, too, that that instrument is melodic and horizontal and that the true song never atop. There are no waste-spaces-the hall-mark of the amateur-in his songs, no empty streets with dogs snuffing in the dustbins. The battleship in "Homeward Bound " moved on as surely to Dover as the " Old Superb" to Trinidad. Bteam or sail, thirty knots or five, they never stopped. Schubert knew it too. There are no waste spaces in " Der Erlkönig " or " An die Musik " or " Das Lied im Grünen." Go to the greatest song in the world, " Der Doppelgänger," the very embodiment of silence, of immobility, of trance, of death in life. Here, if ever, we should find the fermata in possession; yet it moves ever on inexorable, throbbing, alive, without a pause, to the great despair. Just a few chords, a few declamatory sentences ordered and joined with an almost supernatural economy of mesns, the same 
economy which is conspicuous in such modern songs as Butterworth's "Requiescat" or Boughton's "Immanence," and which is as much the secret of art as it is of nature.

This Schubertian economy of effort is inherent in all Btanford's songs and goes hand in hand with the rapidity with which ho writes. I remember once sending him the tune and words of "Molly Brannigan," which I had just received from Miss Galwey, with a peremptory demand for its immediate "arrangement" and return. It went off at 9 a.m. and was back in my house in its present setting, tune, text, arrangement and transport complete, at 11.80 -in about the time I should have taken to copy the notes. The setting is simplicity itself, it is true, but absolutely appropriate. It could have been done in the time only by a writer whose technical expression was so spontaneous 88 to be involuntary.

Dr. Alcock has told me of an even more remarkable instance of this. He asked him one day at the Royal College if he could make an orchestral setting of his chant to the 150th Psalm for a special Festical performance at Salisbury Cathedral. He gave him the chant at 2 o'clock and got it back, fully scored (in groups), verse by verse, at 3.

There is something fascinating in this power of going direct for what you want to say and saying it in the fewest number of notes without stopping to think how you do it. It brings all the qualities I have spoken of above within the play of the composer's imagination and ensbles him to dress them up and exploit them in turn or together as members of one big happy family. "What could be more exhilarating then the swish of the bellows in "A Fire of Turf" or the sailing of the ships at dawn in the first of the "Fleet-Bongs"; more intoxicating than the rhythm of " Devon, O Devon," or "The Old Buperb," or "The Fair "? For mastery of words what could beat "To the Boul " or "Tears" or " Grandeur" or " Did you ever?" or "The little Admiral " or "A Boft Day"? They seem to be speech glorifledwhat song should be-oxalted to high music with an uncanny esse, and with the same spontaneity of expression as the widely differing songs of sheer drama such as "La belle Dame sans merci" and the "Corsican Dirge."

Of all Stanford's songs perhaps the best known is the "Fairy Lough" from the "Irish Idyll." Both the famous poem and the music are classics by now. I doubt if there is another pianoforte-song in existence which contains so much imagery and musioal illustration in a short space. I should like to show how it strikes the singer who looks at it from within, though at the end of it the reader may wonder what the singer has to do with it. It is not widely sung because the average singer, alas I does not realise that his only place in music is to deliver a message. The analysis is my own, and made without consultation with the composer, and does not profess to be anything but an imaginative picture inspired by the music. 


\section{THE FAIRY LOUGH.*}

Loughareema | Loughareema Lies so high among the hesther;

A little lough, a dark lough, The wather's black an' deep.

Ould herons go a-fishin' there, An' sea-gulls all together

Float roun the one green island On the fairy lough asleep.

Loughareema, Loughareema ; When the sun goes down at seven, When the hills are dark an' airy, "Tis a curlew whistles sweet!

Then somethin' rustles all the reeds

That stand so thick an' even;

A little wave rung up the shore An' flees, as if on feet.

Loughareema, Loughareema ! Stars come out, an' stars are hidin'; The wather whispers on the stones, The flittherin' moths are free.

One'st before the mornin' light The Horsemen will come ridin' Roun' an' roun' the fairy lough, An' no one there to see.

MoIra O'NerLl.

$\mathrm{H}_{\theta}$, the composer, with his intimste knowledge of values, saw that the singer, however great his self-restraint and command of colour, was too muah of the earth earthy to paint that picture appropriately with his voice. Let him flght it as he would, he could not resist the temptation to show you the trees instead of the wood, and the audierice would be conscious of his personality instead of the atmosphere of the song. If you read the poem through you will find that it is pervaded throughout by the spirit of remoteness. The little black lake lies so far away, so high among the hesther, thet the fairies and the ses-gulls and the herons have it all to themselves. You (the ginger) are there by stealth, probably with the connivance of a Leprechaun. If you show in your voice that you are looking on, the harons will see you and flap off, the sea-gulls will wake up and the fairies will go home to bed. How then can the picture be painted? It is all thero-in the acompaniment-whispered so gently, so subtly, that the audience holds its breath to hear; and not a fairy is the wiser.

- Mears. Williem Bleckrood and Bons end Messrs. Booses and Do. have kindly given permission for the inclasion of the poem and of the musical extrects. 
The "Fairy Lough" is a berceuse. It is rocked upon the little waves which carry the sleeping sea-gulls round and round the little green island for ever and evar.
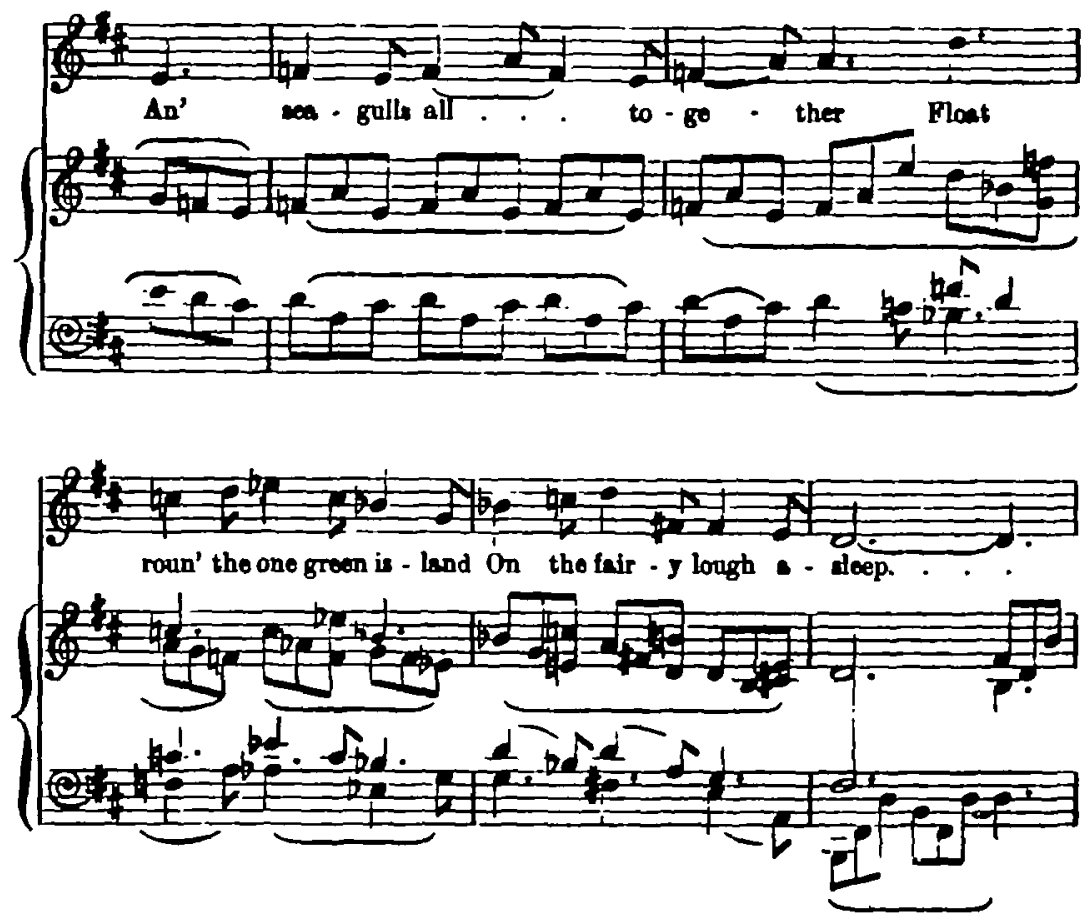

Some of the waves are longer and deeper. When you flrat see the little black lake it seems to be breathing softly, almost imperceptibly.
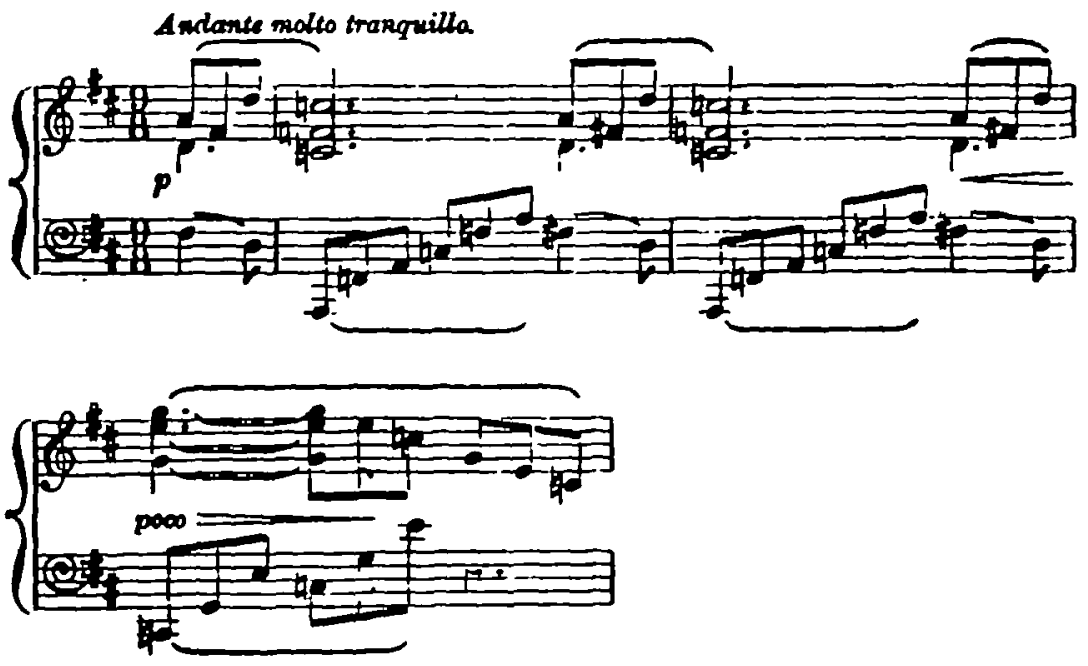
But when they reach the shore they get very amall, and run up the strand and back again and laugh under their breath.
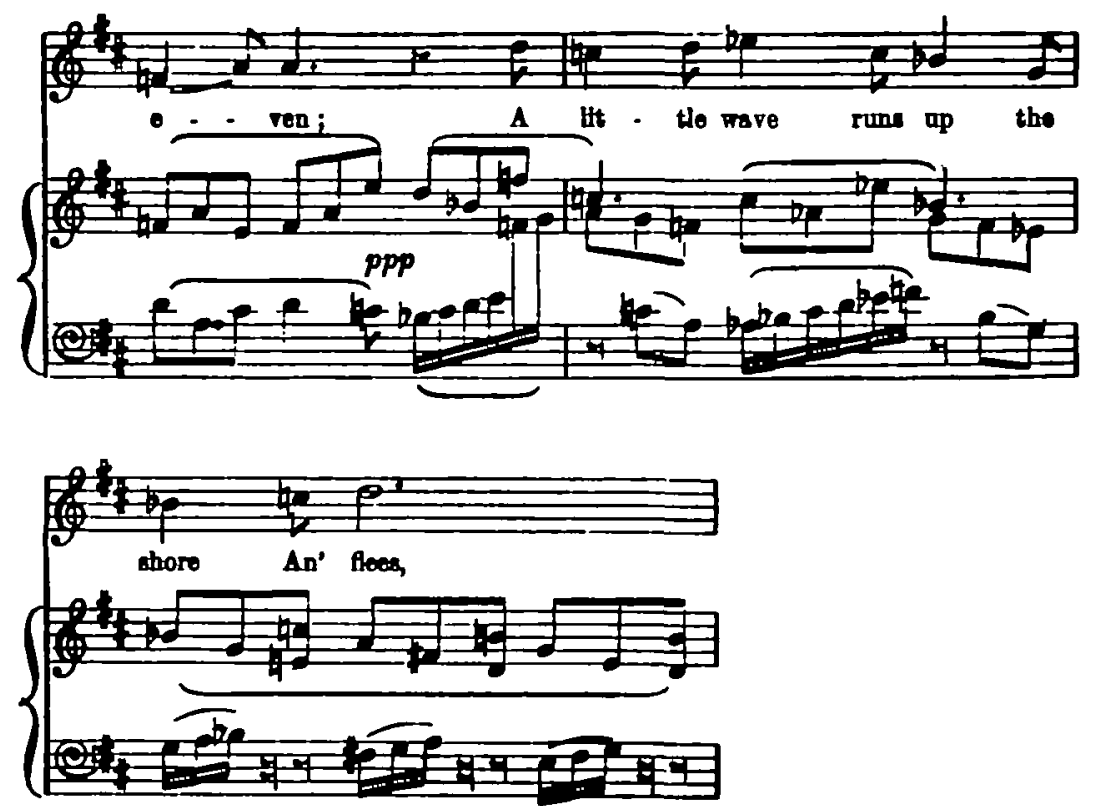

And as you watch them you hear the curlew calling in the sky high up above the dark hills.
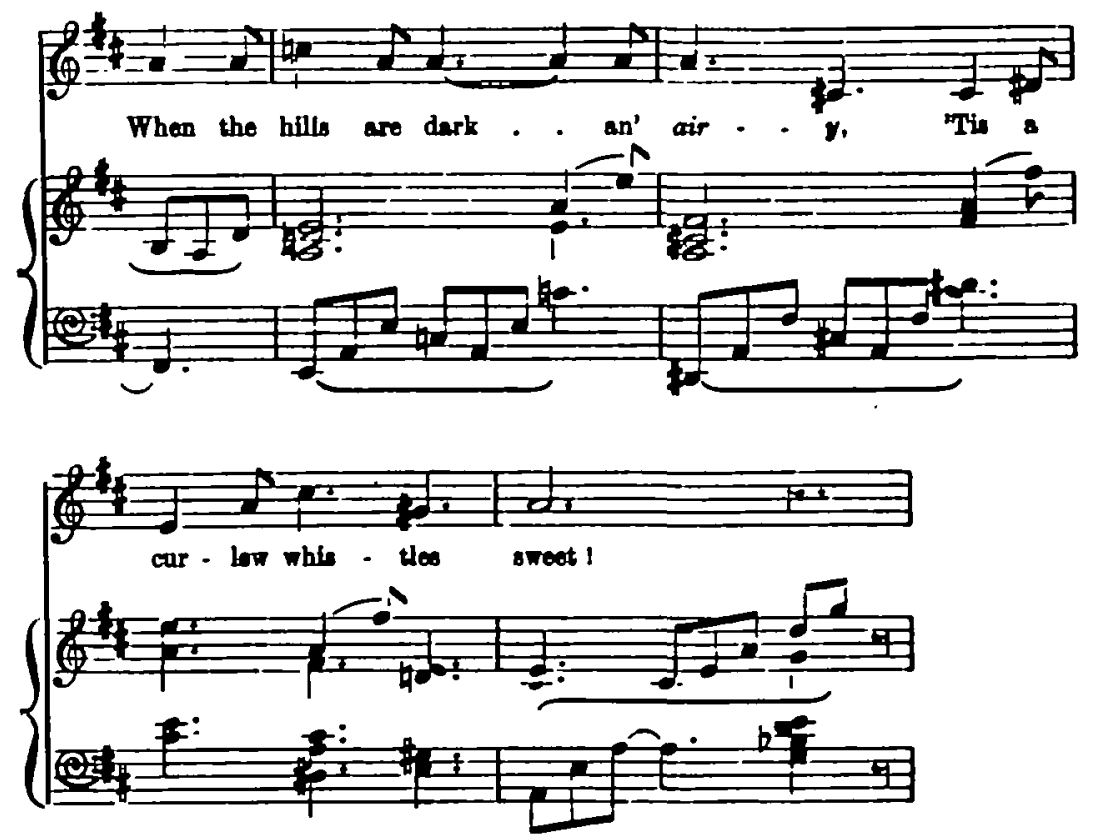
And down below you hear the water whisper o'er the stones at your feet, and the moths flitter round your head; and as the first light comes up in the East you hear the Horsemen gallop up to tell them the day is at hand, and ride off into the distance.
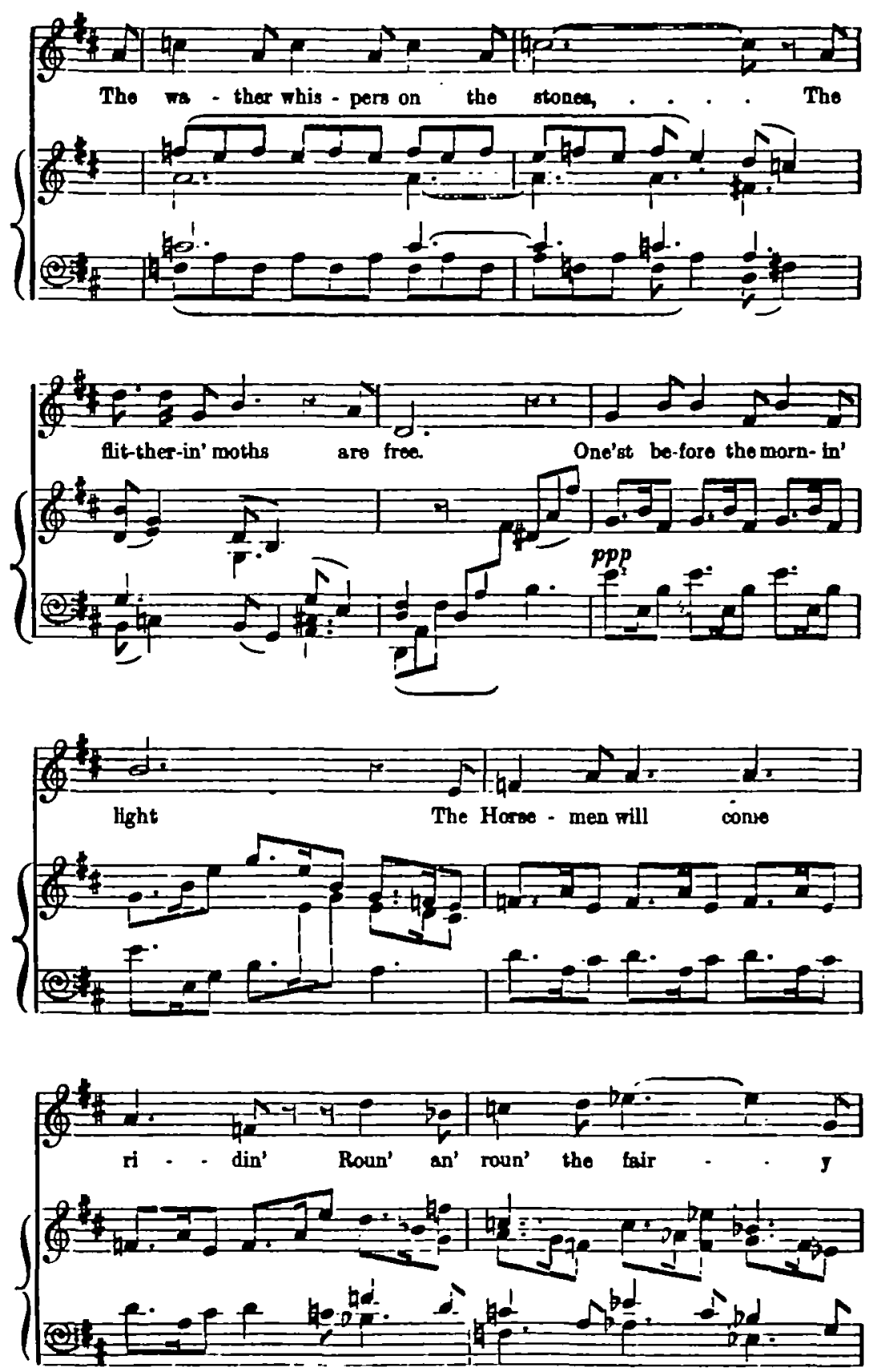


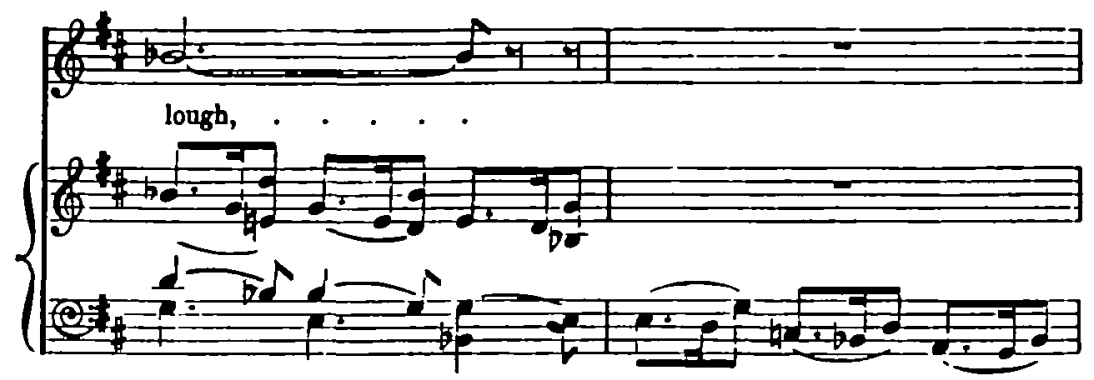

And perhaps you will find the moment when you look away from the water and up at the sky and watch the stars come out; and later on the place where you stand up before you say "Goodbye." There is no more space to give the music here.

I spoke of the spirit of remoteness which is in the poem. The music is saturated with it. It is given to you in the $F$ major chord in the very first bar. The $C$ natural lifts you away from earth at once, and you find it constantly recurring throughout. It is the "colour" feature of the song and sets the atmosphere for the singer at the start.

There is not, and never was, a singer who would not wake the seagulls up if he made vivid what he saw. It has nothing to do with technique or virtuogity; it is simply the human element in the human voice which disqualifies it as a fairy illustrator. What, then, can be his share in the scheme? He can tell you under his breath that it is a littlo lough and a dark lough, and that the water's black and deep -by his colour; that the water whispers and the reeds rustle and the moths fitter-by his word-illustration; that the sea-gulls flost round and round the little island with their heads under their wings, spellbound-by his phrasing. He can help to tell you that the Horsemen are coming to announce the dawn-by his rhythm; and he can say "Goodbye" and again "Goodbye" on the two final "Loughareemas" as be steals back down the hill just before the $\mathrm{D}$ major chord (coming after the fairy far-off $F$ major) tells you that the sun is up and the tairies are gone each and every one of these a miniature of miniatures ; but his real place in the song is just to say that the little lake " lies so high among the heather," that there's " no one there to see."

Three crowded minutes of imagination without a jostle anywherel There is not a bar which is not painting the picture or adumbrating the atmosphere, each leading into the next with a perfection of sequence, a master-joinery so easy as to be laughable. There is not a chord or a note which you could pick out as having been used for a plank to carry you scross the ditches. It floats on as unconcernedly as the sea-gulls themselves. And it is done within the compass of a miniature of miniatures, played and sung for the most part $p p$, where a stumble 
or a splash would make you jump as though someone had thrown a stone into the water.

Let me point out again that the voice and the accompaniment do not paint the picture by turns. There are no alternating patches of colour; they do it together. Let the reader get the song and see for himself how every detail contributes to, and is lost in, the whole. It does not differ in this respect from any other true work of art. It happens to be a masterpiece capable of analysis and demonstration.

Let the young composer, too, take note that in this intimate illustrated tone-picture there are only four expression marks in the voice part, and those in the vital places. 0 , si sic omnes!

It is mastery of technique which gives that directness of purpose and rapidity in translating the idea into the written note of which I spoke above and which I have so often seen when these songs were in the making. The composer who has to make detours is on all fours with the singer who changes his words to suit his easy vowels. Music is about the only thing in the world in which the longest way round is not the shortest way home. I would ask the student especially to take Stanford's songs-at random if he likes-and study the piano. forte part. He will find that there is not a passage or chord in any of them which has not $n$ definite meaning and which is not friends with its neighbour; and that technically it is as easy to play as the voice part is to sing. The only time $I$ ever heard an aspersion cast upon his pianoforte technique was at a concert at the Folian Hall, where he was accompanying me in the "Irish Idyll." Harold Samuel, who happened to be playing at the same concert, was turning over for him, and in the rapid ascending passage at the end of "Cuttin' Rushes" I distinctly heard behind me, sotto voce, in lightning thrust and parry, the words "Fakel" and "Liarl", neither being in the original text.

I wish there were space to analyse some of the other songs in the same way, to show the instant appeal they make to the interpreterthe "painted ship upon the painted ocean " of the " Middle Watch "; the nostalgia of "Corrymeela" and "Irish Bkies"; the hypnotic trnnce of "La belle Dame sans merci"; the breathless drams of "The Corsican Dirge"; the shivers and smiles of "How does the wind blow?" the antioyclone and the collapse of the barometer in "The West Wind "; the broken heart of the "Broken Bong "; the rippling brook of " Cuttin' Rushes "; the physical fatigue of " Blackberry-time"; the rocking of the "Boat Bong "; the mysticiam of "Drake's Drum"; the battle-ary of "Devon, O Devon"; the long rollers of "Homeward Bound"; the distances and symbolism of "The Pibroch"; the Schumannesque rhapsody of "The Call "; the Navy spirit of the " Little Admiral"; the home spirit of "Cughendnll," with the curlews borrowed from the "Fairy Lough" (pure singing in excelsis); and the passionate dirge and triumph of "Fare- 
well "-not touched on, suggested, adumbrated, but the spirit of each permeating the song as a whole as the breath of its body.

It would be easy to demonstrate the working of the big dramatic songs and show how the composer has given himself elbow-room and at the same time kept the song in the miniature form and the singer from getting out of hand. 13ut drama tells its own story and is directly visible to the eye. In music it is subtlety not obviousness which is the mark of genius and appeals most to the interpreter who cares to look beneath the surface. I would ask the reader to conaider "Grandeur," the first of the " Sheaf of Songs from Leinster." This is a soliloquy, pathetic and grimly humorous, a bare statement of fact for the most part, as far removed from paint and powder as the Mary Byrme of the truly wonderful poem. It is said to oneself, not sung to an audience, and its colour never changes, the colour which creeps into the voice which is on the verge of tears. Painting pictures here would be murder, and well the composer knew it. He left it to the words. There is only one piece of direct illustration in the whole of it, namely, where he suggests the wailing of the " keen," vivid enough at an Irish wake to rouse you out of any soliloquy. He knew that elaboration and ornament were as far removed from Mary Byrne in death $a s$ in life, so he just set the strings of emotion vibrating and left it to the singer.

The eng is in this respect the antithesis of the "Fairy Lough," and just es subtle. I have quoted it for that reason, and because it as subtly discloses the humour which I believe to be the main driving power of everything he has written. $\mathrm{He}$ is the only British composer that I have ever come across whose humour is non-sporadic. Most of our song writers have written an odd song or two either frankly humorous or leaning towards humour, just to say they could do it. But it is part of Btanford's permanent mental outfit, and comes out in everything he writes. There is humour in Mary Byrne's lying-instate, as there is in the little waves that run up the shores of the Fairy Lough (how Bach must have chuckled when he wrote the Fugue in $G$ sharp minor l); in the curtseying of the tables in the roll of the Sou' wester; in the similar figure for the space-destroying stride of "Daddy Longlegs," and the quotation from the " Feuerzauber " when he burns his wings in the candlo-not pointed out like most quotations, but flung out like a laugh as you ride by; in the shudders and heartthumpings and sprints through the dark lanes of "Scared "; in the grim-comic analogies of "The Crow"; or in the threatenings and slaughters of "The Bold Unbiddable Child," with the two mighty smsoks upon the culprit in the two final chords. Like his versatility, it is probsbly one of the products of the land of his birth, and none the worse for that. It makes a sympathetic appenl to his countryman, who once heard him say in a burst of righteous indignation in the card room, "I did lead my longest suit. They were all the same length." 
This article deals only with his original songs; otherwise I could have shown how he has handled the setting of the traditional melodies. It is not too much to say that the whole sohool of " unselfish " folksong arrangers is founded on his treatment of "The Songs of Old Irelsnd " and the other collections of Irish airs. It would be hard to beat " Sweet Isle" or " The little red Lark" or " Remember the Poor " for the setting of a jewel; or "The Alarm" or " Loved Bride of O'Byrne" for rhythmical expression of the primitive emotions. There is no branch of the art so dependent upon economy of technique. It was fortunate for us that he was there at the start to show us the way.

I said at the beginning that durability wns the only sure test of soundness. Will the songs last? Well, "The radiant Dark" (1871), "La belle Dame sans Merci" (1876), " Blue Winge" (1878), "The Lute Song" (1875), "Prospice" (1880), the "Cavalier Songs" (1880), and the "Bower of Roses" (1877), are as fresh to-day as when they were born, and that is from 40 to 50 years ago; and these are but a few of many. There are no youthful indiscretions to make you blush when you stumble on them; no cheap resuscitations by the heartless publisher. Wherever you come across them, and whatever period they belong to, you find the same imagination served by the mind that was trained in the Greek and Latin classics and the hand that was trained in the workshop. Modern idiom may be differentas no doubt it should be, for idiom is inherently ephemeral and changes with every generntion. But the great mes of each remain, for there are no goodbyes in immortality. Time has shown us that genius schooled is independent of time or season, and that imagination and workmanship are the parents of every abiding work of art, whether it be a.corbel from York Minster or a sword from Japan or a song from Ireland.

Haris Pluxket Greexe. 